\title{
IN VITRO ORGANOGENESIS OF RANGPUR LIME ${ }^{1}$
}

\author{
LEONARDO SORIANO ${ }^{2}$, EVELINE CARLA DA ROCHA TAVANO ${ }^{3}$, MAUREL BEHLING ${ }^{4}$, \\ FRANCISCO DE ASSIS ALVES MOURÃO FILHO ${ }^{5}$, BEATRIZ MADALENA JANUZZI MENDES
}

ABSTRACT - Rangpur lime (Citrus limonia Osbeck) in vitro organogenesis was studied based on explant type and cytokinin culture media supplementation. Four explants types collected from epicotyl or hypocotyl regions of in vitro germinated seedlings were evaluated. The epicotyl-derived explants consisted of epicotyl segments and the hypocotyl-derived explants consisted of the entire hypocotyl segment, the hypocotyl segment attached to a cotyledon fragment, and the hypocotyl segment divided longitudinally. The explants were cultured on EME culture medium supplemented with benzylaminopurine $\left(0,0.5,1.0\right.$, or $\left.1.5 \mathrm{mg} \mathrm{L}^{-1}\right)$. The evaluation was performed after 6 weeks. Best results considering both the explant responsiveness and number of shoots developed per explants were obtained when epicotyl segments-derived explants were evaluated. Considering the explant responsiveness of hypocotyl segments-derived explants no difference was detected between the entire hypocotyl segment and the hypocotyl segment attached to a cotyledon fragment. Moreover, the percentage of responsive explants decreased when hypocotyl segments divided longitudinally were tested. No difference was detected for the number of shoots developed per explant considering the three types of hypocotyl-derived explants. Culture media supplementation with BAP was not essential for Rangpur lime in vitro organogenesis. However, adventitious shoot development was stimulated in concentrations between $0.5-1.0 \mathrm{mg} \mathrm{L}^{-1}$.

Index terms: adventitious shoot; Citrus limonia; tissue culture.

\section{ORGANOGÊNESE IN VITRO DE LIMÃO CRAVO}

RESUMO - A organogênese in vitro de limão Cravo (Citrus limonia Osbeck) foi estudada em função do tipo de explante e da suplementação do meio de cultura com citocinina. Foram avaliados quatro tipos de explantes coletados da região do epicótilo e do hipocótilo de plântulas germinadas in vitro. Os explantes consistiram em segmentos de epicótilo, segmentos de hipocótilo, segmentos de hipocótilo ligado a um fragmento do cotilédone e segmentos de hipocótilo cortado longitudinalmente. Os explantes foram cultivados em meio de cultura EME suplementado com benzilaminopurina $\left(0 ; 0,5 ; 1,0\right.$ e $\left.1,5 \mathrm{mg} \mathrm{L}^{-1}\right)$. As avaliações foram realizadas após seis semanas de incubação, e os melhores resultados considerando-se tanto a porcentagem de explantes responsivos como o número de gemas desenvolvidas por explante foram obtidos com o uso de segmentos de epicótilo como explante. Considerando os explantes derivados da região do hipocótilo, não foi detectada diferença na porcentagem de explantes responsivos com o uso de segmentos de hipocótilo ou de segmentos de hipocótilo ligado a um fragmento do cotilédone. A porcentagem de explantes responsivos diminuiu com o uso de segmentos de hipocótilo cortado longitudinalmente como explante. Não foi detectada nenhuma diferença no número de gemas adventícias desenvolvidas por explante considerando-se os três tipos de explantes derivados da região do hipocótilo. A suplementação do meio de cultura com BAP não é essencial para a organogênese in vitro de limão Cravo. No entanto, o desenvolvimento de gemas adventícias foi estimulado com concentrações entre $0,5-1,0 \mathrm{mg} \mathrm{L}^{-1}$.

Termos para indexação: gema adventícia, Citrus limonia, cultura de tecidos.

\footnotetext{
'(Trabalho 151-11). Recebido em: 13-05-2011. Aceito para publicação em: 02-05-2012.

${ }^{2}$ Engenheiro Florestal - Pós-graduando - Universidade de São Paulo/ Escola Superior de Agricultura "Luiz de Queiroz", C.P. 9 13418-900 - Piracicaba-SP - Brasil. E-mail: 1soriano@cena.usp.br

${ }^{3}$ Bióloga - Pós-graduanda - Universidade de São Paulo / Centro Nacional de Energia Nuclear na Agricultura - Laboratório de Biotecnologia Vegetal, C.P. 96-13400-970 - Piracicaba-SP - Brasil. E-mail: ectavano@cena.usp.br

${ }^{4}$ Engenheiro Agrônomo - Pesquisador - Empresa Brasileira de Pesquisa Agropecuária / Agrossilvipastoril - Pesquisa \& Desenvolvimento, CEP 78550-003 - Sinop-MT - Brasil. E-mail:maurel.behling@embrapa.br

${ }^{5}$ Engenheiro Agrônomo - Professor - Universidade de São Paulo / Escola Superior de Agricultura "Luiz de Queiroz" - Departamento de Produção Vegetal, C.P. 9-13418-900 - Piracicaba-SP - Brasil. E-mail: famourao@esalq.usp.br

${ }^{6}$ Engenheira Agrônoma - Professora - Universidade de São Paulo / Centro Nacional de Energia Nuclear na Agricultura - Laboratório de Biotecnologia Vegetal, C.P. 96-13400-970 - Piracicaba-SP - Brasil. E-mail: bmendes@cena.usp.br
} 


\section{INTRODUCTION}

Citrus genetic transformation has been studied since 1989 (KOBAYASHI; UCHIMIYA, 1989) with the production of transgenic plants of different citrus species and cultivars. However, the results obtained so far indicate that some genotypes are recalcitrant to the process. Rangpur lime (C. limonia), sour orange (C. aurantium), and volkamer lemon $(C$. volkameriana) are among the rootstocks cultivars which problems have been detected regarding genetic transformation. These problems may be related not only with gene transfer process but also to a low efficiency of in vitro organogenesis.

The success in in vitro citrus culture is related to genotype (KHAN et al., 2009), explant type (TAVANO et al., 2009), culture media composition (COSTA et al., 2004; SILVA et al., 2008), and incubation conditions (MOLINA et al., 2007). Most citrus in vitro organogenesis protocols are based on the culture of young tissue, mainly epicotyls and intermodal segments (GARCIA-LUIS et al., 1999; MOURA et al., 2001) cultivated in culture media supplemented with cytokinin (BORDÓN et al., 2000; ALMEIDA et al., 2002). For Rangpur lime these protocols have not shown a high efficiency. Since the first studies of citrus in vitro culture Rangpur lime is described as one of the genotypes that reacts slowly and produces few shoots per explants (BARLASS; SKENE, 1982). Recently, Almeida et al. (2002) and Costa et al. (2004) reported an explant responsiveness of $60 \%$ when epicotyls segments of Rangpur lime were cultured in absence or low concentrations of benzylaminopurine $\left(0.5 \mathrm{mg} \mathrm{L}^{-1}\right)$, and higher concentrations of cytokinin inhibited in vitro organogenesis. When internodal segments were used as explant, the development of adventitious shoots was detected in $62 \%$ of the explants culture in culture media supplemented with $2.5 \mathrm{mg} \mathrm{L}^{-1}$ of BAP. Comparing this numbers with values of explant responsiveness obtained for other genotypes, such as 95\% for Troyer and Carrizo citrange (MOREIRA-DIAS et al., 2001; BORDÓN et al., 2000), 90\% for grapefruit (COSTA et al., 2004), and $96 \%$ for C. aurantifolia (PÉREZ-MOLPHEBALCH; OCHOA-ALEJO, 1997) Rangpur lime can be considered a recalcitrant genotype.

Recently, Tavano et al. (2009) improved the protocol of in vitro organogenesis for sour orange and volkamer lemon using an alternative explant consisted of hypocotyl segment attached to a cotyledon fragment. The authors related an explant responsiveness improvement from 42 to $77 \%$ for volkamer lemon, and from 59 to $75 \%$ for sour orange. Moreover, it was detected that the adventitious shoots developed only at the hypocotyl end of the explant.

The aim of this research was to study the adventitious shoots development of Rangpur lime from epicotyl and hypocotyl segments-derived explants cultured in culture media supplemented with benzylaminopurine.

\section{MATERIALS AND METHODS}

\section{Plant Material}

Seeds were extracted from mature fruits of Rangpur lime and dried at room temperature (24 h). The seed coat was removed and the seeds were treated with sodium hypochlorite solution $(0.5 \%$ active chloride, $20 \mathrm{~min}$ ), followed by three rinses with sterile distilled water. Epicotyl segments-derived explants $(0.8 \mathrm{~cm})$ were extracted from seedlings (12 $-15 \mathrm{~cm}$ in height) germinated in test tubes $(25$ x $150 \mathrm{~mm})$ containing MT solid medium $(15 \mathrm{~mL}$; MURASHIGE; TUCKER, 1969) incubated at $27^{\circ} \mathrm{C}$, in the dark (3 - 4 weeks) and transferred to $16 \mathrm{~h}$ photoperiod $\left(65 \mu \mathrm{mol} \mathrm{m} \mathrm{m}^{-2} \mathrm{~s}^{-1}\right)$ for $10 \mathrm{~d}$. Hypocotyl segments-derived explants were extracted from seeds germinated in Magenta boxes containing MT solid medium $(40 \mathrm{~mL})$ incubated in the dark for $20 \mathrm{~d}$. The hypocotyl-derived explants consisted of the entire hypocotyl segment $(0.8 \mathrm{~cm})$, the hypocotyl segment attached to a cotyledon fragment as described by Tavano et al. (2009), and the hypocotyl segment divided longitudinally.

\section{In vitro organogenesis}

The explants were horizontally cultured in Petri dish $(100 \times 15 \mathrm{~mm})$ containing MT salts and vitamins medium (MURASHIGE; TUCKER, 1969) supplemented with 6-benzylaminopurine (BAP; 0, $0.5,1.0,1.5 \mathrm{mg} \mathrm{L}^{-1}$ ), incubated firstly in the dark for $30 \mathrm{~d}$ and then transferred to $16 \mathrm{~h}$ photoperiod. Evaluation was performed after $45 \mathrm{~d}$ in culture to determine both the number of responsive explants and the number of shoots per explant with the help of a stereomicroscope (Zeiss, Oberkochen, Germany). The experimental design was completely randomized with 3 or 5 replications. Each replication consisted of a Petri dish with 4 or 8 explants. The experiments were repeated four times. The data were analyzed by ANOVA. The means of the different explants types were compared by Tukey's test. The influence of BAP concentrations was studied by regression analyses.

This study was performed in the Plant Biotechnology Laboratory, at the Centro de Energia Nuclear na Agricultura/USP, Piracicaba/SP, Brazil. 


\section{RESULTS AND DISCUSSION}

After six weeks in culture the development of adventitious shoots could be detected in all explants types evaluated (Figure 1). A higher number of responsive explants were obtained when epicotyl segments-derived explants were evaluated, regardless the BAP concentration tested. The percentage of responsive explants for epicotyl segments-derived explants was twice as much the values obtained for the hypocotyl segments-derived explants (Tables 1 and 2).

Most citrus in vitro organogenesis protocols are based on the culture of epicotyl segments-derived explants which results in the development of a high number of adventitious shoots that reflects in a high efficiency of genetic transformation. However, in some recalcitrant genotypes even using this young and less differentiated explants the results are not as expected. These difficulties encourage the study of other types of explants.

Hypocotyl segments have been described as a very responsive explants for species other than citrus such as passion flower (FERNANDO et al., 2007; PINTO et al., 2010), cotton (DIVYA et al., 2008), and Eucommia ulmoides (CHEN et al., 2008). Hypocotyl segment attached to a cotyledon fragment was described by Ananthakrishnan et al. (2003) as an efficient explant for improving squash in vitro organogenesis. The use of this alternative explant improved in vitro organogenesis of sour orange and volkamer lemon (TAVANO et al., 2009). Moreover, Tavano et al. (2009) detected that in this explant the adventitious buds development occurred always at the hypocotyl end. Based on that information, it was decided to study three different types of hypocotyl segments-derived explants in order to verify the possibility of improving Rangpur lime organogenesis. However contrasting results were obtained for Rangpur lime as the efficiency of in vitro organogenesis of the hypocotyl segments-derived explants was always lower than the efficiency obtained for epicotyl-derived explants.

Considering the different types of hypocotyl segments-derived explants evaluated in this study a better explant responsiveness was obtained for the entire segment and the segment attached to a cotyledon fragment. Cutting the explant longitudinally in order to expose the cambial ring (DUTT; GROSSER, 2009) has been reported as an important factor that may increase citrus organogenesis efficiency (MOURA et al., 2001). However, in this study the lowest explant responsiveness was obtained for hypocotyl segment divided longitudinally.
Regarding the number of shoots developed per explant the best results were also obtained for epicotyl segments-derived explants, with values almost three times as much the values obtained for the hypocotyl segments-derived explants (Table 2). It may be conclude that hypocotyl-derived explants are not adequate for in vitro organogenesis of Rangpur lime.

Considering BAP culture media supplementation, contrasting with other citrus cultivars (GARCÍA-LUIS et al., 1999; MOREIRA-DIAS et al., 2001; MOURA et al., 2001) the presence of cytokinin is not essential for adventitious bud development. The percentage of responsive explants was stimulated with BAP concentrations up to $0.55 \mathrm{mg}$ $\mathrm{L}^{-1}$ (Figure 2). In vitro adventitious shoot development in absence or low concentrations of BAP has been reported for Rangpur lime (ALMEIDA et al., 2002; COSTA et al., 2004), and for sour orange (TAVANO et al., 2009) when epicotyl segments-derived explants were used as explant. The culture media supplementation with higher BAP concentrations (higher than $1.0 \mathrm{mg} \mathrm{L}^{-1}$ ) did not lead to a high efficiency in in vitro organogenesis in these recalcitrant genotypes. In addition, high BAP concentrations decrease the percentage of responsive explants. The number of shoots per explant increased with cytokinin culture media supplementation with the best results at the BAP concentration of $0.6 \mathrm{mg} \mathrm{L}^{-1}$, regardless the explant type evaluated (Figure 2 ).

Based on the results obtained in this study, epicotyl segments-derived explants cultured in culture media supplemented with low concentrations of BAP are the best choice for obtaining Rangpur lime in vitro adventitious shoots development. Further studies, considering other parameters that may influence the success of in vitro culture should be carried over in order to improve the efficiency of Rangpur lime in vitro organogenesis. 


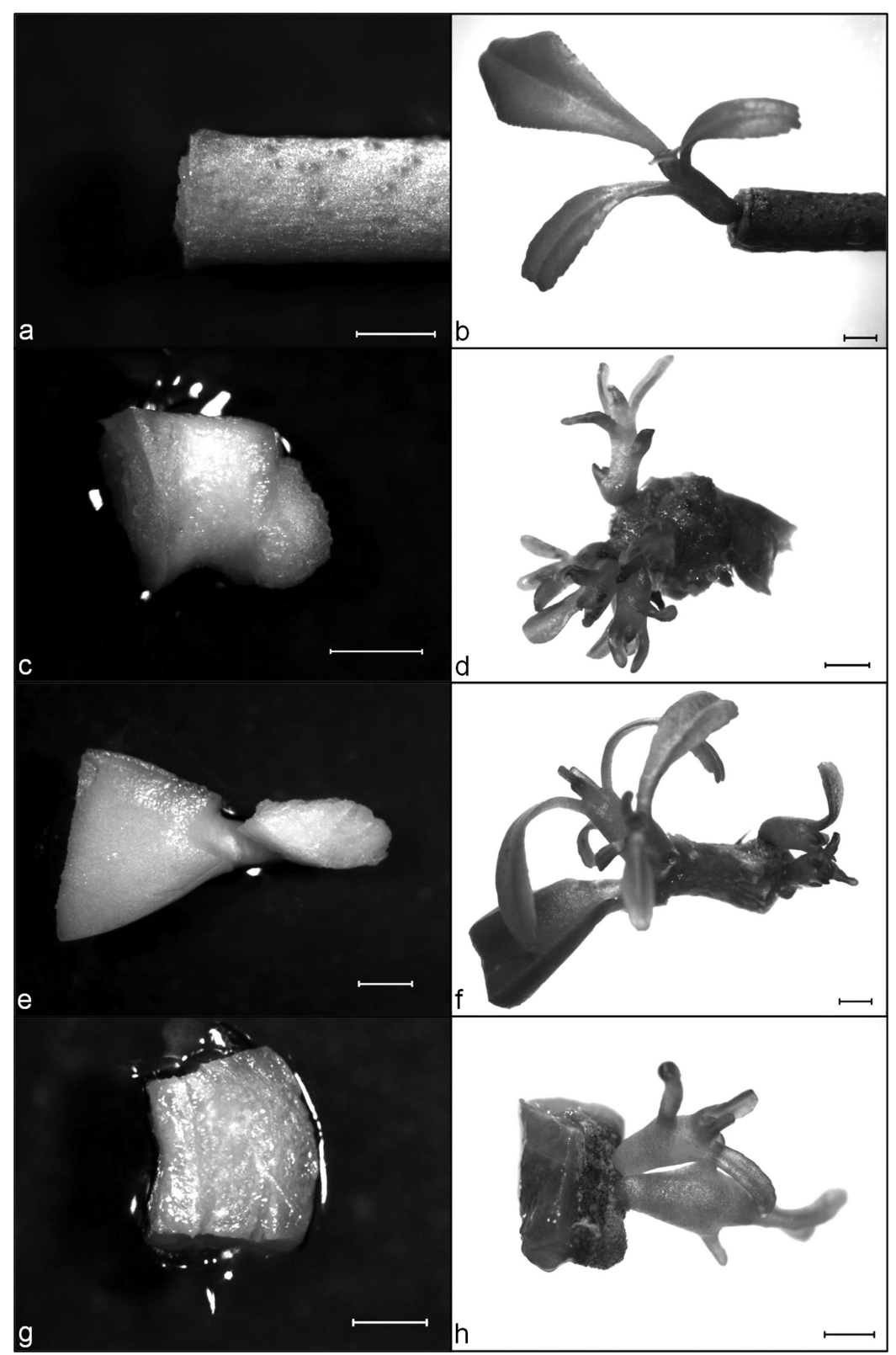

FIGURE 1 - In vitro organogenesis of Rangpur lime developed in the explants epicotyl segment (a-b), hypocotyl segment (c-d), hypocotyl segment attached to a cotyledon fragment (e-f), and hypocotyl segments divided longitudinally $(\mathrm{g}-\mathrm{h})$. Bars $=1 \mathrm{~mm}$. 


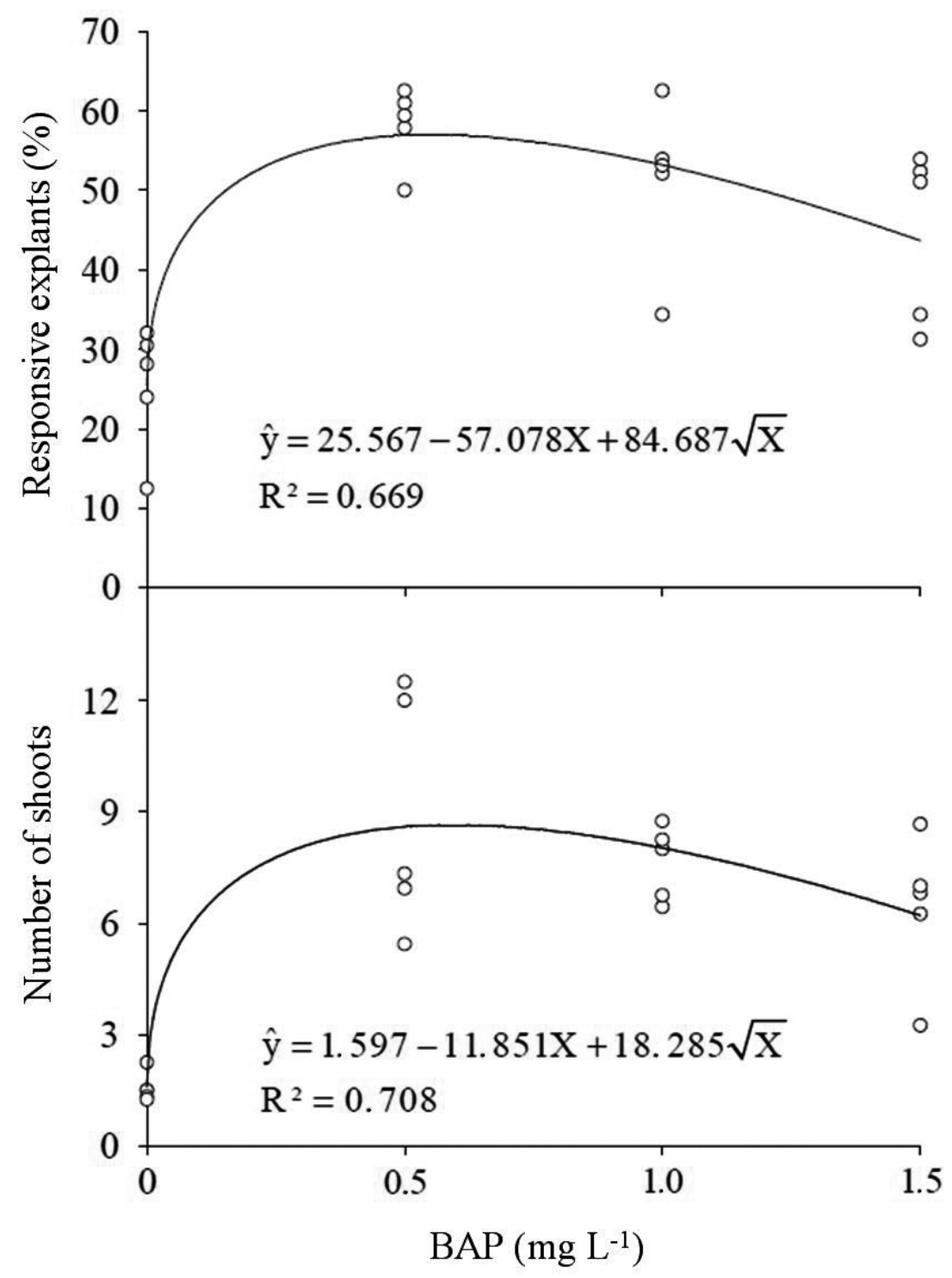

FIGURE 2 - In vitro organogenesis of Rangpur lime considering culture media supplementation with different concentrations of benzylaminopurine (BAP). 
TABLE 1 - In vitro organogenesis of Rangpur lime from epicotyl, hypocotyl, hypocotyl segment attached to a cotyledon fragment, and hypocotyl divided longitudinally, considering the percentage of responsive explants (mean of 4 experiments totaling 85 explants per treatment).

\begin{tabular}{|c|c|c|c|c|c|}
\hline \multirow{2}{*}{$\mathrm{BAP}\left(\mathrm{mg} \mathrm{L}^{-1}\right)$} & \multicolumn{4}{|c|}{ responsive explants $(\%)$} & \multirow{2}{*}{ mear } \\
\hline & epicotyl & hypocotyl & hypocotyl + cotyledon & hypocotyl divided & \\
\hline 0.0 & 66.35 & 20.19 & 17.31 & 7.69 & 27.88 \\
\hline 0.5 & 85.58 & 52.88 & 64.42 & 32.69 & 58.89 \\
\hline 1.0 & 82.69 & 47.12 & 50.96 & 37.50 & 54.57 \\
\hline 1.5 & 91.35 & 42.31 & 33.65 & 30.77 & 49.52 \\
\hline mean & $81.49^{*}$ & $40.63^{\mathrm{ns}}$ & $41.59^{\mathrm{ns}}$ & $27.16^{*}$ & 47.72 \\
\hline
\end{tabular}

TABLE 2 - In vitro organogenesis of Rangpur lime from epicotyl, hypocotyl, hypocotyl segment attached to a cotyledon fragment, and hypocotyl divided longitudinally, considering the number of shoots per explants (mean of 4 experiments totaling 85 explants per treatment).

\begin{tabular}{|c|c|c|c|c|c|}
\hline \multirow{2}{*}{$\mathrm{BAP}\left(\mathrm{mg} \mathrm{L}^{-1}\right)$} & \multicolumn{4}{|c|}{ number of shoots per explant } & \multirow{2}{*}{ mean } \\
\hline & epicotyl & hypocotyl & hypocotyl + cotyledon & hypocotyl divided & \\
\hline 0.0 & 3.31 & 1.46 & 0.85 & 0.38 & 1.50 \\
\hline 0.5 & 12.08 & 5.08 & 6.38 & 6.00 & 7.38 \\
\hline 1.0 & 14.46 & 5.00 & 5.23 & 6.00 & 7.67 \\
\hline 1.5 & 14.69 & 4.85 & 3.46 & 4.23 & 6.81 \\
\hline mean & $11.13^{*}$ & $4.10^{\mathrm{ns}}$ & $3.98^{\mathrm{ns}}$ & $4.15^{\mathrm{ns}}$ & 5.84 \\
\hline
\end{tabular}

\section{ACKNOWLEDGEMENTS}

The authors acknowledge Fundação de Amparo a Pesquisa do Estado de São Paulo (FAPESP) and PPG - Fisiologia e Bioquímica de Plantas ESALQ/USP for financial support and fellowships to Leonardo Soriano, Eveline Carla da Rocha Tavano. Francisco de Assis Alves Mourão Filho and Beatriz M. Januzzi Mendes acknowledge Conselho Nacional de Desenvolvimento Cientifico e Tecnológico (CNPq) for research fellowship.

\section{REFERENCES}

ALMEIDA, W.A.B.; MOURÃO FILHO, F.A.A.; MENDES, B.M.J.; RODRIGUEZ, A.P.M. In vitro organogenesis optimization and plantlet regeneration in Citrus sinensis and C. limonia. Scientia Agricola, Piracicaba, v.59, n.1, p.35-40, 2002.

ANANTHAKRISHNAN, G.; XIA, X.; ELMAN, C.; SINGER, S.; PARIS, H.S.; GAL-ON, A.; GABA, V. Shoot production in squash (Cucurbita pepo) by in vitro organogenesis. Plant Cell Reports, Berlin, v.21, n.8, p.739-746, 2003.
BARLASS, M.; SKENE, K.G.M. In vitro plantlet formation from Citrus species and hybrids. Scientia Horticulturae, Amsterdam, v.17, n.4, p.333-341, 1982.

BORDÓN, Y.; GUARDIOLA, J.L.; GARCÍA-LUIS, A. Genotype affects the morphogenic response in vitro of epicotyl segments of Citrus rootstocks. Annals of Botany, Oxford, v.86, n.1, p.159-166, 2000.

CHEN, R.; NAMIMATSU, S.; NAKADOZONO, Y.; BAMBA, T.; NAKAZAWA, Y.; GYOKUSEN, K. Efficient regeneration of Eucommia ulmoides from hypocotyl explant. Biologia Plantarum, Dordrecht, n.4, v.52, p.713-717, 2008.

COSTA, M.G.C.; ALVES, V.S.; LANI, E.R.G.; MOSQUIMA, P.R.; CARVALHO, C.R.; OTONI, W.C. Morphogenic gradients of adventitious bud and shoot regeneration in epicotyl explants of Citrus. Scientia Horticulturae, Amsterdam, v.100, n.1, p.63-74, 2004. 
DIVYA, K.; SWATHI-ANURADHA, T.; JAMI, S.K.; KIRTI, P.B. Efficient regeneration from hypocotyl explants in three cotton cultivars. Biologia Plantarum, Dordrecht, v.52, n.2, p.201-208, 2008.

DUTT, M.; GROSSER, J.W. Evaluation of parameters affecting Agrobacterium-mediated transformation of citrus. Plant Cell, Tissue and Organ Culture, Dordrecht, v.98, n.3, p.331-340, 2009.

FERNANDO, J.A.; VIEIRA, M.L.C.; MACHADO, S.R.; APPEZZATO-DA-GLÓRIA, B. New insights into the in vitro organogenesis process: the case of Passiflora. Plant Cell, Tissue and Organ Culture, Dordrecht, v.91, n.1, p.37-44, 2007.

GARCÍA-LUIS, A.; BORDÓN, Y.; MOREIRADIAS, J.M.; MOLINA, R.V.; GUARDIOLA, J.L. Explant orientation and polarity determine the morphogenic response of epicotyl segments of Troyer citrange. Annals of Botany, Oxford, v.84, n.6, p.715-723, 1999.

KHAN, E.H.; FU, X.Z.; WANG, J.; FAN, Q.J.; HUANG, X.S.; ZHANG, G.N.; SHI, J.; LIU, J.H. Regeneration and characterization of plants derived from leaf in vitro culture of two sweet orange (Citrus sinensis (L.) Osbeck) cultivars. Scientia Horticulturae, Amsterdam, v.120, n.1, p.70-76, 2009.

KOBAYASHI, A.; UCHIMIYA, H. Expression and integration of a foreign gene in orange (Citrus sinensis Osb.) protoplasts by direct DNA transfer. Japanese Journal of Genetics, Mishima, v.64, n.2, p.91-97, 1989.

MOLINA, R.V.; CASTELLÓ, S.; GARCÍA-LUIS, A.; GUARDIOLA, J.L. Light-cytokinin interactions in shoot formation in epicotyl cuttings of Troyer citrange cultured in vitro. Plant Cell, Tissue and Organ Culture, Dordrecht, n.2, v.89, p.131-140, 2007.
MOREIRA-DIAS, J.M.; MOLINA, R.V.; GUARDIOLA, J.L.; GARCÍA-LUIS, A. Day length and photon flux density influence the growth regulator effects on morphogenesis in epicotyl segments of Troyer citrange. Scientia Horticulturae, Amsterdam, v.87, n.4, p.275-290, 2001.

MOURA, T.L.; ALMEIDA, W.A.B.; MENDES, B.M.J.; MOURÃO FILHO, F.A.A. Citrus in vitro organogenesis related to BAP concentrations and explant section. Revista Brasileira de Fruticultura, Jaboticabal, v.23, n.2, p.240-245, 2001.

MURASHIGE, T.; TUCKER, D.P.H. Growth factor requirements of citrus tissue culture. In: CITRUS SYMPOSIUM, 1., 1969, Riverside. Proceedings... Riverside: University of California, 1969. p.11551161.

PÉREZ-MOLPHE-BALCH, E; OCHOA-ALEJO, $\mathrm{N}$. In vitro plant regeneration of Mexican lime and Mandarin by direct organogenesis. HortScience, Alexandria, v.32, n.5, p.931-934, 1997.

PINTO, A.P.C.; MONTEIRO-HARA, A.C.B.A.; STIPP, L.C.L.; MENDES, B.M.J. In vitro organogenesis of Passiflora alata. In Vitro Cellular and Developmental Biology - Plant, Bethesda, v.46, n.1, p.28-33, 2010.

SILVA, R.P.; MENDES, B.M.J.; MOURÃO FILHO, F.A.A. In vitro induction and culture of adventitious buds in epicotyl segments of sour orange. Pesquisa Agropecuária Brasileira, Brasília, v.43, n.10, p.1331-1337, 2008.51

TAVANO, E.C.R.; STIPP, L.C.L.; MUNIZ, F.R.; MOURÃO FILHO, F.A.A.; MENDES, B.M.J. In vitro organogenesis of Citrus volkameriana and Citrus aurantium. Biologia Plantarum, Dordrecht, v.53, n.2, p.395-399, 2009. 